\title{
海岸線急変部に設置された突堤と離岸堤の漂砂 制御効果の比較
}

\author{
芹沢 真澄1 ・宇多 高明 2 宮原 志帆3 \\ 1正会員＼cjkstart海岸研究室（有）（†160-0011 東京都新宿区若葉1-22 ローヤル若葉301） \\ E-mail:coastseri@nifty.com \\ 2正会員（一般財団）土木研究センター常務理事なぎさ総合研究室長兼日本大学客員教授理工学部海洋 \\ 建築工学科（干110-0016 東京都台東区台東1-6-4） \\ E-mail:uda@pwrc.or.jp \\ 3海岸研究室（有）（†160-0011 東京都新宿区若葉1-22 ローヤル若葉301） \\ E-mail:qqqu4vdd@aroma.ocn.ne.jp
}

\begin{abstract}
急勾配海岸において海岸線方向が急変する場所で発達する円弧状砂州の特性を移動床模型実験によって 調べた８時間の波作用後，砂州上に突堤を設置することにより突堤の沿岸漂砂阻止効果を調べた上で, 実験結果に対してBGモデルを適用したところ，海岸線急変部での砂州の変形がうまく計算された。 さら に, 海岸線方向の急変部にできた砂州上に離岸堤が設置された場合の地形変化についても実験と計算を行 い, 突堤と離岸堤の漂砂制御効果の比較を行った.
\end{abstract}

Key Words : Cuspate foreland, BG model, movable bed experiment, groin, detached breakwater

\section{1. はじめに}

汀線沖に海底谷が迫るような海岸では，入射波高・波 向の場所的変化が大きく，また急勾配斜面を経た海底谷 への土砂落ち込みも起こり得ることから, 直線状海岸と は異なるパターンの海浜変形が起こる．このような条件 を満足する海岸では, 従来から海岸保全のために使われ てきた突堤や離岸堤の建設は条件によっては海底谷への 土砂流出を助長することになる. 日本三大急深湾のひと つである駿河湾の西岸に位置する清水海岸では，L字突 堤の北側で海底谷への細砂の流出が観測された1).また 富山湾に面した下新川海岸の荒俣地先では, 海底谷近傍 の陸棚上に造られた離岸堤が，結果的に海底谷への土砂 流出を促していることが見出された2).さらに相模湾に 面した森戸川河口沖の海底谷背後の海岸では，従来から 海底谷への土砂落ち込みが見られたが，海底谷背後の海 岸で突堤を延ばすと海底谷への土砂落ち込みが助長され ることが数值モデルにより明らかにされた3).このよう に汀線沖に海底谷が迫る海岸での海岸保全については, 直線状のフラットな海岸とは大きく異なる現象が見られ る. 宇多・山本 ${ }^{4}$ は, この種の問題に関連して, 砂の堆 積域が急深な場合には海岸線急変部で円弧状砂州が形成 されることを移動床模型実験により示した.またこのよ
うな場での海浜変形予測は従来困難であったが，芹沢ら 5)は，BGモデル（Bagnold概念に基づく3次元海浜変形モ デル）を上記実験結果に適用することにより，3次元的 な地形変化の予測を初めて可能とした。本研究では芹沢 ら5゙が提案したBGモデルを, 円弧状砂州の周辺で海岸保 全のために突堤あるいは離岸堤を設置した場合の海浜変 形予測に適用し，急深海岸におけるこれらの構造物の設 置が周辺海浜へ及ぼす影響の相互比較を行った。

\section{2. 円弧状砂州の発達に関する模型実験}

芹沢ら ${ }^{5)}$ は, 宇多・山本 ${ }^{4)}$ が幅 $16 \mathrm{~m}$, 長さ21 m平面水 槽を用いて行った円弧状砂州の発達に関する移動床模型 実験結果を4.で述べるBGモデルの検証材料として用いた. 本研究でも自然状態での円弧状砂州の形成についてはこ れと同じデータを用いた。この場合の模型海浜材料には 中央粒径 $0.28 \mathrm{~mm}$ の砂が用いられ, 水槽中央より右側に は砂の供給源を造る一方，左側には1/5の急勾配海岸を 造った上で, 左向きの沿岸漂砂により下手側へと砂が運 ばれる条件とされた．初期汀線への法線と波の入射方向 とのなす角は沿岸漂砂が十分発達する条件として20 が 選ばれた。また砂の供給源となる海浜の高さは水面上10 
$\mathrm{cm}$ とした．実験波は換算沖波波高が $H_{0}{ }^{\prime}=4.6 \mathrm{~cm}$, 周期が $T=1.27 \mathrm{~s}$ の規則波，作用時間は8時間であった.

図-1(a), 1(b)は初期形状と造波開始8時間後の海浜形状 を示す。なお，図-1(a)には造波開始直後に測定した砕波 点（矢印の先端），砕波波高（矢印の大きさ）および入 射方向（矢印の向き）を示す．砂の堆積域の水深が大き いため砂が急勾配をなして堆積し，8時間後には海岸線 急変部に円弧状砂州が形成された.

宇多らのは，上記実験結果に加え，波浪条件を同一に 保ちつつ円弧状砂州の上手端に突堤を設置して左向きの 沿岸漂砂を阻止した場合の海浜変形を調べた。自然状態 で8時間の波の作用で形成された海浜（図-1(b)）におい

\section{(a) initial stage}

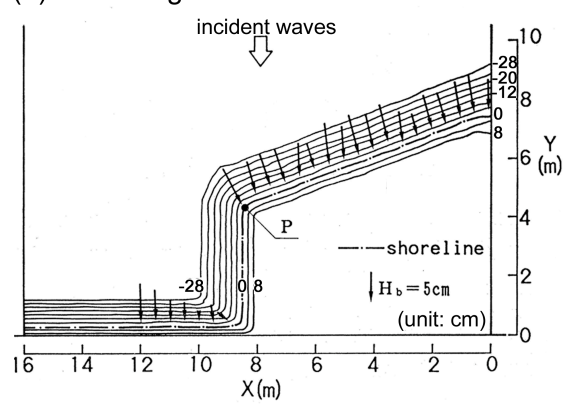

(b) $t=8 \mathrm{hrs}$

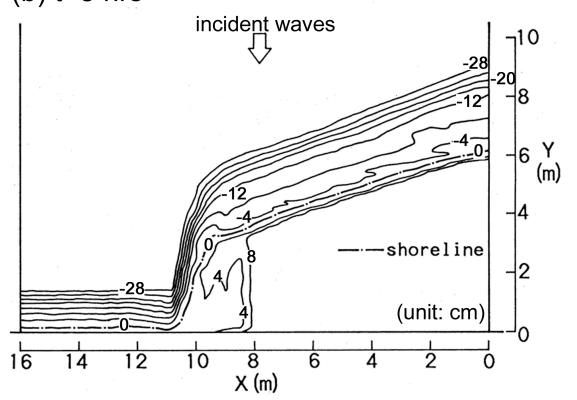

(c) $t=8 \mathrm{hrs}$ after installation of a groin

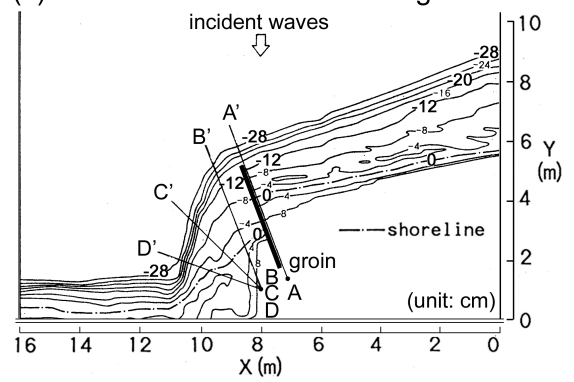

図-1＼cjkstart海岸線屈曲部における円弧状砂州の発達と 突堤設置後の地形変化（模型実験）

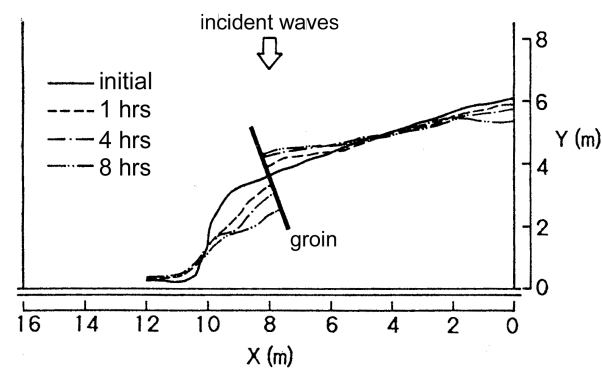

図-2＼cjkstart汀線変化（実験）
て，突堤を設置しさらに8時間波を作用させた（図1(c)）. 突堤により沿岸漂砂が阻止された結果，突堤下 手側では浅海域の等深線が大きく後退し侵食緩斜面が形 成された，突堤設置後の汀線の時間的変化を図-2に示す. 突堤を境に汀線が不連続となり，とくに突堤下手側では 当初ら状であった汀線が時間経過とともに凹状となった こと，また突堤下手では著しい汀線の後退が起きたこと が分かる.

\section{3. 予測モデル}

芹沢ら ${ }^{5)}$ のBモデルをもとに地形変化予測を行った. 計算の基本式には，砕波波高の沿岸方向勾配に起因する 沿岸漂砂量を考慮するためのOzasa and Brampton 項”をを付 加した式（1）を用いた.

$$
\begin{gathered}
\vec{q}=C_{0} \frac{P}{\tan \beta_{\mathrm{c}}}\left\{\begin{array}{c}
K_{n}\left(\tan \beta_{c} \overrightarrow{e_{w}}-|\cos \alpha| \overrightarrow{\nabla Z}\right) \\
\left.+\left\{\left(K_{s}-K_{n}\right) \sin \alpha-\frac{K_{2}}{\tan \bar{\beta}} \frac{\partial H}{\partial s}\right\} \tan \beta \overrightarrow{e_{s}}\right\} \\
\left(-h_{c} \leq Z \leq h_{R}\right)
\end{array}\right. \\
P=\rho u_{m}^{3}
\end{gathered}
$$

$$
u_{m}=\frac{H}{2} \sqrt{\frac{g}{h}}
$$

ここに, $\vec{q}=\left(q_{x}, q_{y}\right)$ はネットの砂輸送フラックス, $Z(x, y$, t) は地盤高， $n$ およびsは等深線直角方向（岸向き）およ び平行方向に取った局所座標, $\overrightarrow{\nabla Z}=(\partial Z / \partial x, \partial Z / \partial y)$ は 地形の勾配ベクトル， $\overrightarrow{e_{w}}$ は波向の単位ベクトル， $\overrightarrow{e_{s}}$ は 等深線平行方向の単位ベクトル， $\alpha$ は波向と等深線直角 方向のなす角, $\tan \beta=|\overrightarrow{\nabla Z}|$ は海底勾配, $\tan \beta_{c}$ は平衡勾 配, $\tan \beta \overrightarrow{e_{s}}=(-\partial Z / \partial y, \partial Z / \partial x), K_{s}, K_{n}$ はそれぞれ沿岸・ 岸沖漂砂量係数, $K_{2}$ はOzasa and Brampton項の係数, $\partial H / \partial s=\overrightarrow{e_{s}} \cdot \overrightarrow{\nabla H}$ は等深線平行方向に測った波高 $H の$ 勾配, $\tan \bar{\beta}$ は砕波帯の代表海底勾配である。 また $C_{0}$ は水中重 量表示加ら体積表示への換算係数 $\left(C_{0}=1 /\left\{\left(\rho_{s}-\rho\right) g(1-p)\right\} ; \rho\right.$ は海水の比重, $\rho_{s}$ は砂の比 重, $p$ は砂の空隙率, $g$ は重力加速度）, $u_{m}$ は波の底面振動流 速振幅, $H$ は波高, $h$ は水深, $h_{c}$ は波による地形変化の限界 水深, $h_{R}$ はバーム高である.

波浪場の計算には，実験での規則波を不規則波と見な して，不規則波の方向スペクトル $D(f, \theta)$ を変数とする Mase $^{8}$ によるエネルギー平衡方程式の数值計算法を用い た. 波の打ち上げ領域での波浪場の計算には，芹沢ら 5 と同様仮想水深を設定し，仮想水深 $h$ ’を式(4)で与えた.

$$
h^{\prime}=\left(\frac{h_{R}-Z}{h_{R}+h_{0}}\right)^{r} h_{0} \quad(r=1) \quad\left(-h_{0} \leq Z \leq h_{R}\right)
$$


表-1 計算条件

\begin{tabular}{|c|c|}
\hline Wave conditions & $\begin{array}{l}\text { Incident waves: } \\
H_{I}=4.6 \mathrm{~m}(4.6 \mathrm{~cm}), T=12.7 \mathrm{~s}(1.27 \mathrm{~s}), \\
\text { wave direction } \theta_{\Gamma}=20 \text { relative to normal to } \\
\text { initial shoreline }\end{array}$ \\
\hline Berm height & $h_{R}=5 \mathrm{~m}(5 \mathrm{~cm})$ \\
\hline Depth of closure & $h_{c}=2.5 H$ (H: wave height $)$ \\
\hline Equilibrium slope & $\tan \beta_{c}=1 / 5$ \\
\hline Angle of repose slope & $\tan \beta_{g}=1 / 2$ \\
\hline $\begin{array}{l}\text { Coefficients of sand trans- } \\
\text { port }\end{array}$ & $\begin{array}{l}\text { Coefficient of longshore sand transport } \\
K_{s}=0.045 \\
\text { Coefficient of Ozasa and Brampton }{ }^{7)} \text { term } \\
K_{2}=1.62 K_{s} \\
\text { Coefficient of cross-shore sand transport } \\
K_{n}=0.1 K_{s}\end{array}$ \\
\hline Mesh size & $\Delta x=\Delta y=20 \mathrm{~m}$ \\
\hline Time intervals & $\Delta t=0.001 \mathrm{hr}(0.0001 \mathrm{hr})$ \\
\hline Duration of calculation & $80 \mathrm{hrs}\left(8 \times 10^{4}\right.$ steps $)(8 \mathrm{hrs})$ \\
\hline Boundary conditions & $\begin{array}{l}\text { Shoreward and landward ends: } q_{x}=0 \text {, right } \\
\text { and left boundaries: } q_{y}=0\end{array}$ \\
\hline Calculation of wave field & $\begin{array}{l}\text { Energy balance equation }{ }^{8} \\
\text { - Term of wave dissipation due to wave } \\
\text { breaking: Dally et al. }{ }^{9} \text { model } \\
\text {. Wave spectrum of incident waves: } \\
\text { directional wave spectrum density ob- } \\
\text { tained by Goda }{ }^{10)} \\
\text { - Total number of frequency components } \\
N_{F}=1 \text { and number of directional subdivi- } \\
\text { sions } N_{\theta}=8 \\
\text { - Directional spreading parameter } S_{\text {max }}=75 \\
\text { - Coefficient of wave breaking } K=0.17 \\
\text { and } I=0.3 \\
\text { - Imaginary depth between minimum } \\
\text { depth } h_{0} \text { and berm height } h_{R}: h_{0}=2 \mathrm{~m}(2 \\
\text { cm) } \\
\text { - Wave energy }=0 \text { where } Z \geq h_{R} \\
\text { - Lower limit of h in terms of wave decay } \\
\text { due to breaking } \Phi .0 .7 \mathrm{~m}(0.7 \mathrm{~cm})\end{array}$ \\
\hline Remarks & $\begin{array}{l}\text { Numbers in parentheses show experimental } \\
\text { values. Space and time scales in the calcu- } \\
\text { lation are } 100 \text { - and } 10 \text {-fold those in the } \\
\text { experiment, respectively. }\end{array}$ \\
\hline
\end{tabular}

またバーム高より標高の高い地点では波エネルギーを0 とおいた，本研究では，地形変化に応じた波浪場変化の フィードバック計算を繰り返し行い，地形変化計算10ス テップごとに波浪場を計算し直した。ささら計算の便宜 上，フルード則により宇多・山本 ${ }^{4} の$ 砂觜形成に関する 実験模型の100倍スケール（時間は10倍スケール）を対 象とし，計算結果を $1 / 100$ に縮小して図化した。初期形 状は実験と同様とし，入射波は $H_{\Gamma}=4.6 \mathrm{~m}, T=12.7 \mathrm{~s}$, 波向 は初期汀線に対して 20 の斜め入射とした。 また波によ る地形変化の限界水深は, 任意点の波高を $H$ として $h_{c}=2.5 H$ で与えた. バーム高は $5 \mathrm{~m}$, 砂の平衡勾配は実験結 果に基づいて $1 / 5$, 安息勾配は $1 / 2$ とした. 計算は沿岸方向, 岸沖方向に $20 \mathrm{~m}$ 間隔のメッシュで分割し, $\Delta t=1 \times 10^{-3} \mathrm{hr}$ 時 間間隔で 80 時間 $\left(8 \times 10^{4}\right.$ steps $)$ まで計算を行った。詳細な 計算条件を表-1に示す.

\section{4. 円弧状砂州における沿岸漂砂阻止の影響検討}

\section{（1） 円弧状砂州における沿岸漂砂阻止の影響検討}

図-3は，実験と同一条件を与えて計算した急深海岸で の円弧状砂州の発達予測の結果を示寸．初期に海岸線急 変部で平行に延びていた等深線が波の作用とともに変化 し，8時間後には円弧状の等深線が形成された。 さらに 8 時間波を作用させると，円弧状の砂の堆積域の下手端付 近に形成されていた等深線のくびれは消失し，沿岸方向 の等深線勾配が緩くなった（図-3(c)）。一方，砂の供給 源側では侵食されて平坦面が残された.

次に，実験同様図-3(b)に示した8時間後の地形におい て，図-4(a)のように $X=8 \mathrm{~m}$ に突堤を設置し，その後8時間 波を作用させた場合の予測結果を図-4(b)に示寸．ここに 突堤は不透過の壁体として与えた，突堤が沿岸漂砂を阻 止するため上手側では砂が堆積し沖合の急斜面と連続的 に繋がる急斜面が形成された。これに対して突堤の寸ぐ 下手側の海岸線曲率が大きく，沿岸漂砂量が大きい場所 で沿岸漂砂が遮断されたため，汀線が大きく後退し侵食 緩斜面が形成された。これらの特徴は図-1(c)の実験結果

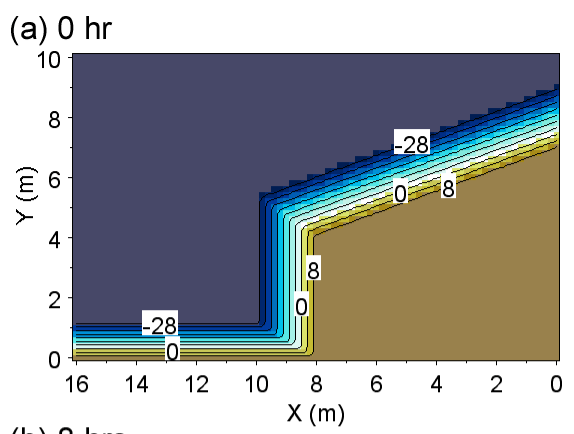

(b) $8 \mathrm{hrs}$

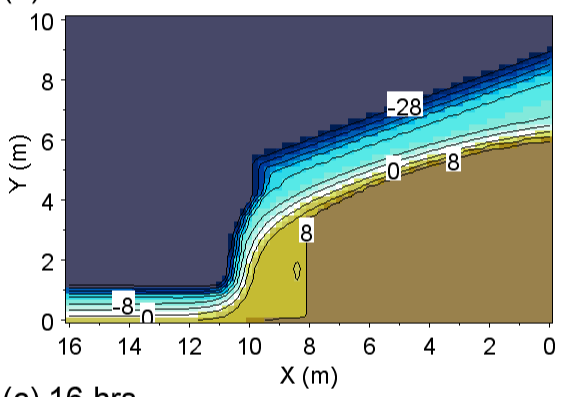

(c) $16 \mathrm{hrs}$

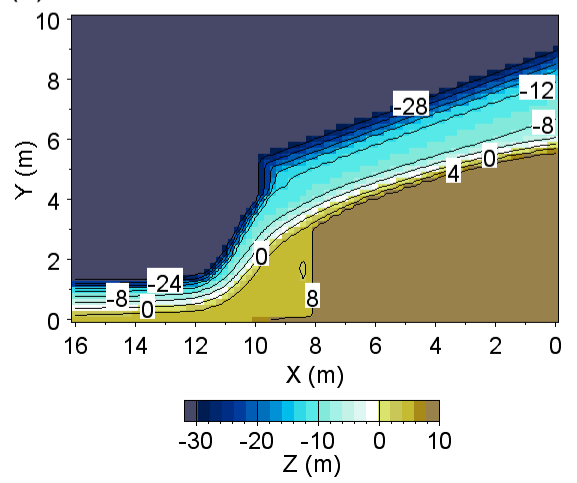

図-3 海岸線屈曲部における円弧状砂州の発達の予測計算結果 
(a) $0 \mathrm{hr}$



(b) $8 \mathrm{hrs}$

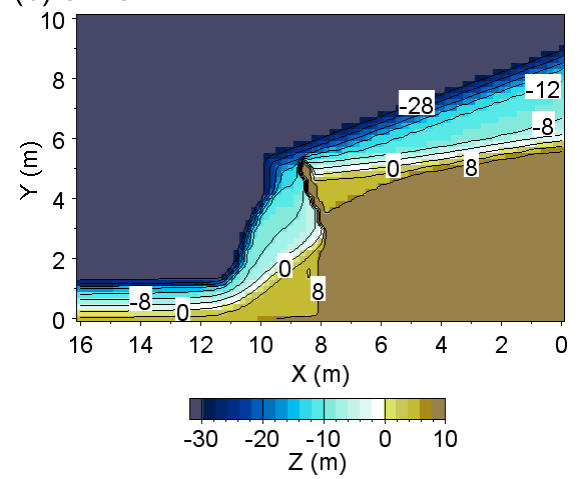

図-4 海岸線屈曲部に突堤を設置した場合の地形変化予測結果

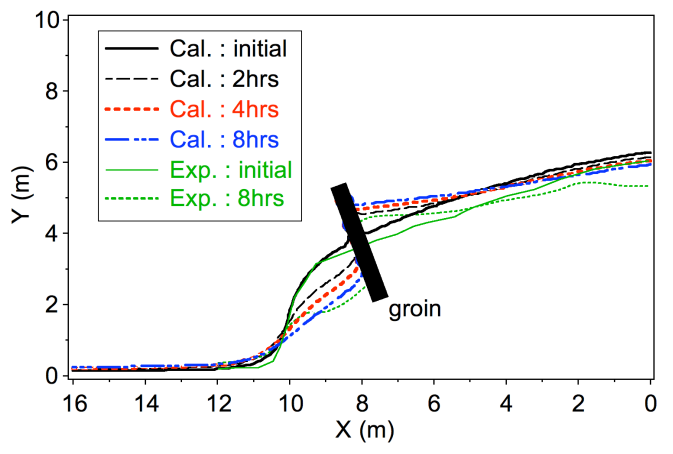

図-5＼cjkstart汀線変化（計算）

\section{をよく説明している.}

図-5は初期から8時間まで2時間間隔での汀線変化の予 測結果と, 初期および8時間後の実験結果を示寸. 計算 では突堤未設置の状態で8時間波を作用させ，この条件 で形成された初期地形に突堤を配置して地形変化予測を 行った. この場合，計算による突堤未設置状態での汀線 変化量は実験結果と比べてやや過小となったため, 計算 の開始時点で実験・計算の汀線形状には差異が残された。 このため実験・計算の0，8時間後両者の值を示し，それ らの変化に注目した．図-5によれば突堤上手側での予 測・実測汀線の変化状況はほぼ一致している．同様に下 手側でも汀線が凹状に後退していく状況について実験と 計算でよい一致を示す，図-6は，図-1に示す4測線の実 験・計算による縦断形変化を示寸．突堤上手側の測線AA’では縦断形の一致度は低いが，変化量で見ればほぼ妥 当な計算結果となっている．また突堤下手側の3測線で はいずれも実験と計算はよく一致している. (a) Transect A-A'

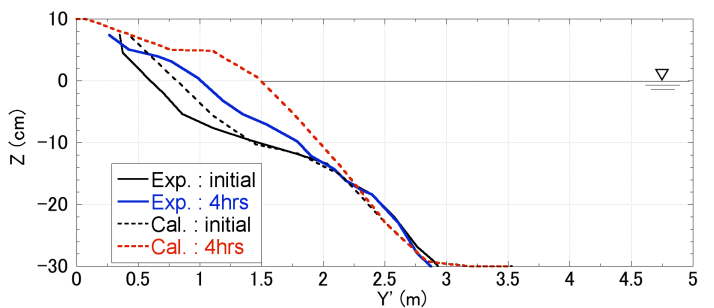

(b) Transect B-B'

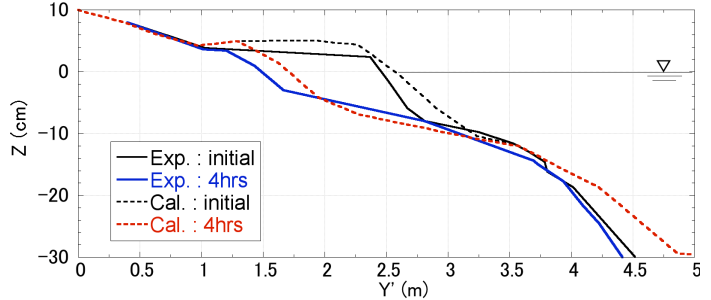

(c) Transect C-C'

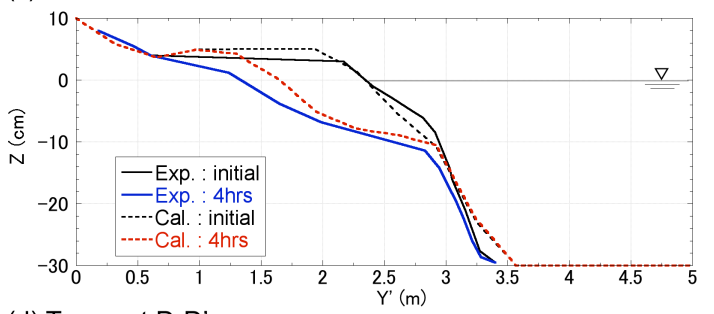

(d) Transect D-D'

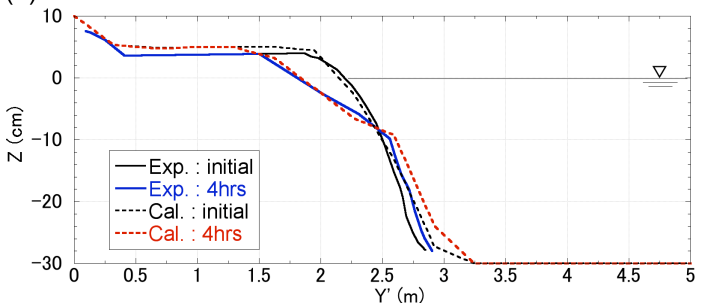

図-6 縦断形変化（実験と計算）

\section{(2) 離岸堤の場合}

次に離岸堤を設置した場合の検討を行った．離岸堤の 設置位置はその中心が $X=8 \mathrm{~m}$ となるようにし, 設置水深 は-8 cmとした．図-6(a)の縦断形変化によれば，突堤上手 側での地形変化は陸上部からほぼZ=-12 cmまでで起きて いることから，この漂砂帯の大部分の砂移動を抑制する 位置とした。

図-7(a)は，図-3(b)に示す8時間後の海浜形状において， 汀線と平行に長さ $1.6 \mathrm{~m}$, 設置水深- $8 \mathrm{~cm}$ の離岸堤を設置 した場合の初期形状を示す。この状態で波を 8 時間作用 させた後の海浜形状を図-7(b)に示す. 離岸堤の上手側で は汀線が離岸堤端部に直線状に繋がる一方，-8 cm と-12 $\mathrm{cm}$ の等深線間隔が離岸堤沖で狭まり, 逆に離岸堤の左 端部では等深線間隔が広がっている。このような等深線 間隔の場所的変化は，離岸堤の上手端では沖向きの，下 手端では岸向きの漂砂が起きており，全体として離岸堤 の上手側から下手側一向から漂砂が起きていることに対 応する. 離岸堤の上手側では等深線が直線状であるが, 下手端ではフック状となっている. 
(a) $0 \mathrm{hr}$

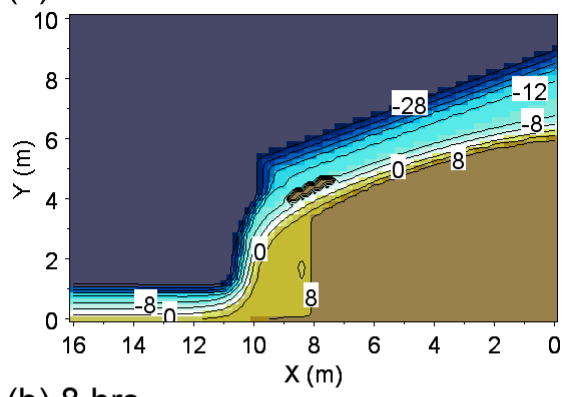

(b) $8 \mathrm{hrs}$

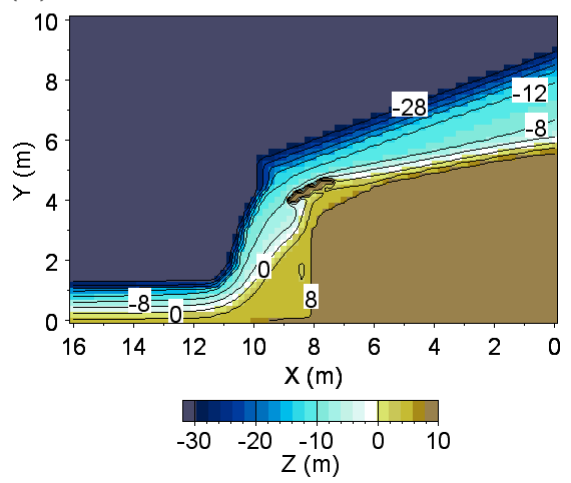

図-7＼cjkstart海岸線屈曲部に離岸堤を設置した場合の 地形変化予測結果

(a) 放置案の地形変化量

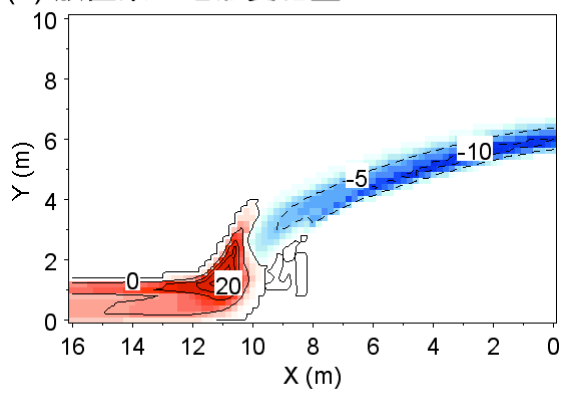

(b) 突堤案の地形変化量

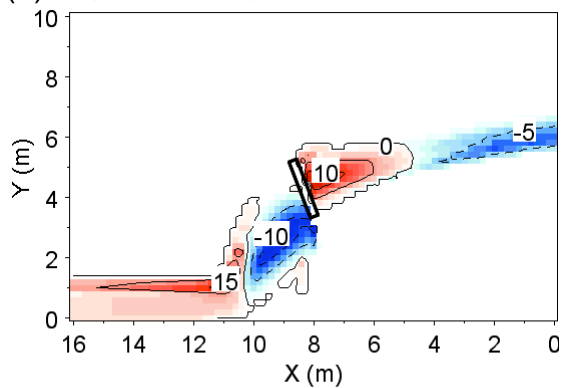

(c) 離岸堤案の地形変化量

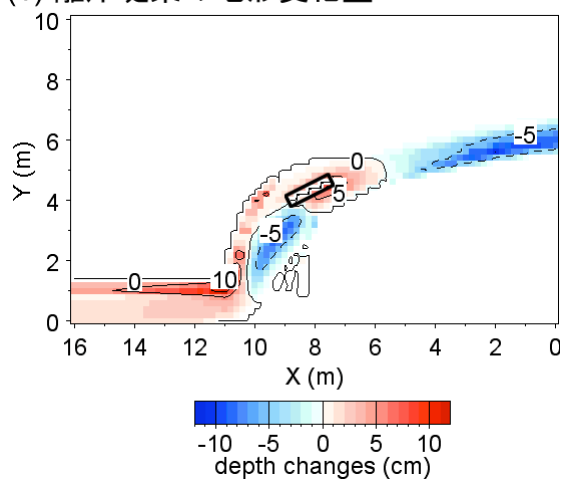

図-8 自然状態と，突堤・離岸堤を設置した場合 の初期地形からの変化量

\section{5. 円弧状砂州周辺に設置された突堤と離岸堤の 機能の差}

図-8(a), 8(b)は，自然状態と突堤を設置した場合におけ る初期からの地形変化量の差, および8時間の波作用後 における自然状態と突堤を設置した場合の地形の差を示 す. 自然状態では $X=8 \mathrm{~m}$ より右側で著しい侵食が起き, そこから沿岸漂砂によって運ばれた砂が海岸線の隅角部 付近に大量に堆積するという変化が起きた. これに対し 突堤が設置されると突堤上手側では沿岸漂砂が阻止され て砂が堆積し，汀線が安定化に向かうため上手端付近で の侵食量も大きく低減している. しかし対照的に突堤の 直下手の侵食は激化する一方, $X=11 \mathrm{~m}$ 付近での堆積量は 減少している.このように突堤の設置は, その上手・下 手に集中的な堆積・侵食を引き起こすことが分かる.

図-8(c)は，8時間の波作用後における自然状態と離岸 堤を設置した場合の地形の差を示す．図-8(b), 8(c)を比較 すると, 突堤の場合には突堤を境として上手側での堆積 と下手側での侵食がきれいに分かれていたが，離岸堤の 場合には離岸堤の上手で堆積, 下手で侵食は起こるもの の, 沿岸漂砂の一部が離岸堤の岸側沖側を通過可能なた めに, 侵食・堆積量も突堤の場合と比べて小さくなった. また最も大きな違いは, 離岸堤の沖合に砂が堆積しつつ 沿岸漂砂の一部が下手側へと通過している点である. こ のように突堤と比べて離岸堤のほうが緩やかな地形変化 となる.また図-8(c)に示すように, 海岸線の屈曲部に形 成された円弧状砂州の上手端付近に離岸堤を設置すると, 一部の沿岸漂砂が離岸堤を迂回して下手側へと移動する が，漂砂の回り込みによる砂の堆積域は離岸堤直下手の 侵食域を大きく囲むようにして延びることが分かる.

図-9(a),9(b)はそれぞれ突堤と放置案の差，およひ離岸 堤と放置案の差を示す，突堤と放置案の差では，突堤を 境に左右で対照的な地形変化が生じている. 一方, 離岸 堤と放置案の差では, 離岸堤の上手側では堆積が起こる と同時に下手側では侵食が起こるが，一部の沿岸漂砂が 離岸堤沖を通過するがゆえに離岸堤沖でも堆積が起きた。

円弧状砂州部分では左向きの沿岸漂砂が連続的に流れ ており，汀線は動的意味で保持されている.これが静的 安定に近い海岸線と根本的意味で異なる点である。この ため強い沿岸漂砂を阻止する施設が造られた場合，その 下手側では著しい侵食が起こる．また突堤の上手側では 沖合の緩斜面上に砂が堆積して海底勾配が急になるにし たがい沖への土砂損失を招きや寸くなる，例えば図-6に 示したA-A'断面における計算結果によれば，初期状態 で-10 cm付近の勾配は1/20であったが，4時間後には汀線 から続く $1 / 5$ の急な一様勾配斜面となり, 綐断形は深海 部へと連続している. 縦断形における平衡勾配は粒径に 対応し，粗な粒径では大きく細い粒径では小さくなるこ 
(a) 放置案と突堤案の差

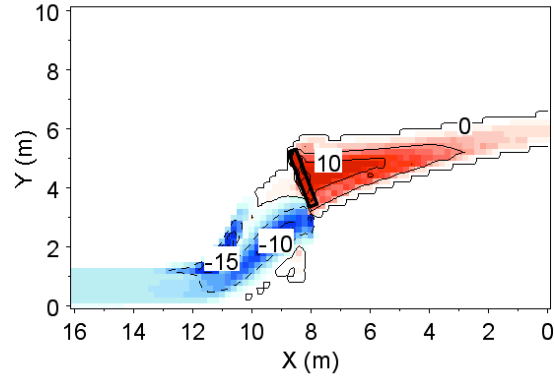

(b) 放置案と離岸堤案の差

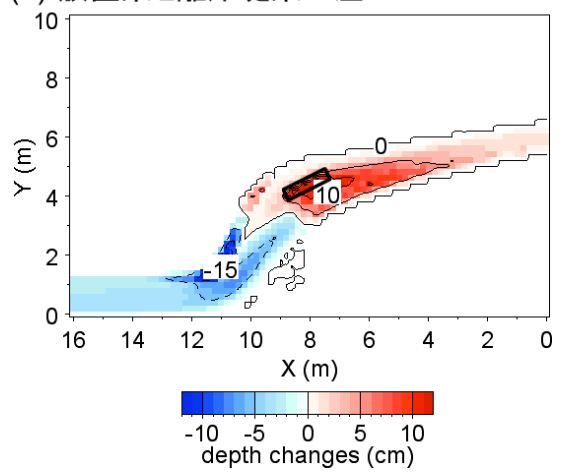

図-9 突堤・離岸堤と放置案との比較

\begin{abstract}
とを考慮すると，図-6に示す突堤上手のA-A'断面では海 底勾配が急になったことから，細い粒径成分は安定性を 失い急勾配斜面を経て深海へと落ち込みやすい条件が造 り出されていることが分かる．実際，この原理に基づく 細砂の深海への落ち込み・損失は清水海岸のL突堤の下 手側で観測された ${ }^{1)}$ 。この結果と比較すると，本実験の ように比較的設置水深が小さい離岸堤の場合，沿岸漂砂 の一部が離岸堤の岸側沖側を通過可能なために，侵食・ 堆積量が突堤の場合と比べて緩やかになる.
\end{abstract}

\section{6. まとめ}

芹沢ら 5゙によって提案されたBGモデルを，宇多らのが 示した急勾配海岸における円弧状砂州の形成と, そこに 突堤および離岸堤が設置された場合の海浜変形予測に適

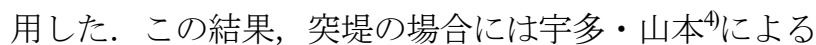
移動床模型実験の結果をBGモデルにより定量的意味か ら再現が可能となった。また海岸線の方向が急变する海 岸に形成された円弧状砂州に離岸堤を設置した場合には, 突堤と異なり沿岸漂砂の一部が下手方向に流れることか ら相対的に緩やかな海浜変形が起こることが明らかにな った.

\section{参考文献}

1) 宇多高明，大橋則和，芹沢真澄，三波俊郎，石川仁 憲，宮原志帆：清水海岸北部の侵食実態とその再現， 海岸工学論文集, 第 56 巻, pp.641-645, 2009.

2) 諏訪義雄，山田浩次，宇多高明，古池鋼，三波俊郎, 石川仁憲，横澤綾：下新川海岸荒俣地先における沖 合への土砂損失機構, 海岸工学論文集, 第 56 巻, pp.631-635, 2009.

3) 宇多高明，高尾治海，秋田和枝，芹沢真澄，三波俊 郎，石川仁憲，横澤綾：海底谷への土砂落ち込みの 予測モデル，海岸工学論文集，第 56 巻，pp.626-630, 2009.

4) 宇多高明, 山本幸次：砂嘴形成海域の海底地形と砂 嘴形態の関係について, 地形, 第 13 巻, pp.141-157, 1992.

5) 芹沢真澄, 宇多高明, 三波俊郎, 横澤綾: 海岸線が急 変する場での砂嘴の発達予測, 地形, 第 31 巻, pp.403-422， 2010.

6) 宇多高明, 山本幸次, 佐口光明, 片岡賢一：砂嘴地 形の安定化工法に関する実験的検討一駿河海岸の和 田鼻砂嘴を例として一, 海岸工学論文集, 第 39 巻, pp.466-470, 1992.

7) Ozasa, H. and Brampton, A. H. : Model for predicting the shoreline evolution of beaches backed by seawalls: Coastal Eng., 4, 47-64, 1980.

8) Mase, H. : Multidirectional random wave transformation model based on energy balance equation, Coastal Eng. J., Japan Society of Civil Engineers, 43(4), 317-337, 2001.

9) Dally, W. R., Dean, R. G. and Dalrymple, R. A. : A model for breaker decay on beaches, Proc. 19th International Conference on Coastal Engineering, 82-97, 1984.

10) Goda, Y. : Random Seas and Design of Maritime Structures, University of Tokyo Press, Tokyo, 323p., 1985.

\section{COMPARISON OF BEACH CHANGES AROUND CUSPATE FORELAND CAUSED BY INSTALLATION OF A GROIN AND DETACHED BREAKWATER}

\section{Masumi SERIZAWA, Takaaki UDA and Shiho MIYAHARA}

The development of a cuspate foreland on a steep coast with abrupt change in coastline orientation was investigated by a movable bed experiment. After 8-hour wave generation, a groin was installed at the cuspate foreland and the effect of obstructing continuous longshore sand transport was also experimentally investigated. The results of the experiment were reproduced using the BG model which was proposed by the present authors. The beach changes around the cuspate foreland were successfully predicted. The experimental and numerical results were in good agreement. The installation of a detached breakwater on a steep coast with abrupt change in coastline orientation was also predicted using the model and both results were compared. 